\title{
Ekspresi Relatif mRNA BRLF1 Epstein-Barr Virus dari Biopsi Jaringan Tumor dalam Blok Parafin sebagai Petanda Biologi Patogenesis Karsinoma Nasofaring
}

\author{
Andreanne Poppy Estania ${ }^{1}$, Hidayat Sulistyo ${ }^{2}$, Daniel Joko Wahyono ${ }^{1}$ \\ ${ }^{1}$ Fakultas Biologi, Universitas Jenderal Soedirman \\ ${ }^{2}$ Fakultas Kedokteran, Universitas Jenderal Soedirman \\ Email: danieljokowahyono@yahoo.com.
}

\begin{abstract}
Nasopharyngeal carcinoma (NPC) is a malignant tumor of epithelial cells of the nasopharynx and is a multifactorial disease that is geographically endemic in the world. The undifferentiated carcinoma is the most common type of NPC and strongly associated with Epstein-Barr virus (EBV) infection. BRLF1 lytic gene is required for the switch from latent to lytic infection. The pathogenesis of NPC is more directly reflected by carcinoma-specific viral transcriptional activity at the site of primary tumor. The aim of this study was to determine the relative expression of mRNA BRLF1 EBV in NPC WHO-3 patient as a potential biomarker of NPC pathogenesis, particularly in tumor progressivity in NPC. This research designed by an analytical observasional research with a cross sectional study. The samples were the tissue biopsies formalin-fixed embedded paraffin (FFPE) of 24 NPC patients at Pathology Anatomy Departement, RSUD. Prof. dr. Margono Soekarjo, Purwokerto. The relative expression of mRNA BRLF1 EBV was determined by RT-qPCR technique and calculated by Livak \& Schmittgen formula $\left(2^{-\Delta C t}\right)$. The relative expression of mRNA BRLF1 EBV in NPC WHO-3 patients on advanced staging was approximately start from 99.04415959 to 1097.496026. In NPC WHO-3 patients, the relative expression of mRNA BRLF1 EBV in early stage $(n=5 ; 544,72420 \pm 142,614733)$ increased of 1.8 times compared to late stage $(n=17 ; 395,68612 \pm 293,172201)$, however it was no significance differences statistically $(n=17 ; \mathrm{df}=1 ; \mathrm{p}=0,13)$. Therefore, the relative expression of mRNA BRLF1 EBV from tissue biopsies FFPE are not potensial biomarker of NPC pathogenesis, particularly in tumor progressivity on advanced staging.
\end{abstract}

Key Words : Biomarker pathogenesis, NPC, Relative expression of mRNA BRLF1 EBV BRLF1

\begin{abstract}
Abstrak
Karsinoma nasofaring (KNF) merupakan tumor ganas pada sel epitel nasofaring dan merupakan penyakit multifaktor yang bersifat endemik. Tipe KNF tidak berdiferensiasi (KNF WHO-3) telah terbukti konsisten dengan infeksi EBV. Gen litik BRLF1 berperan sebagai mediator transisi dari fase laten menjadi litik. Pengukuran aktivitas mRNA EBV di lokasi tumor primer perlu dilakukan karena lebih mencerminkan patogenesis KNF yang sesungguhnya dari pada diagnosis serologi dan pengukuran DNA EBV di sirkulasi darah. Penelitian ini bertujuan untuk mengetahui nilai ekspresi relatif mRNA BRLF1 Epstein-Barr Virus pada beberapa tingkat stadium tumor penderita KNF sebagai petanda biologi potensial dalam patogenesis KNF. Metode penelitian yang digunakan adalah metode deskriptif yang berbentuk studi seran lintang. Sampel penelitian ini adalah biopsi jaringan tumor dalam blok parafin penderita KNF sebanyak 24 sampel. Sampel tersebut telah didiagnosis pasti sebagai KNF WHO-3 dari hasil pemeriksaan Patologi Anatomi pada Poli Patologi Anatomi, RSUD Prof. Dr. Margono Soekarjo, Purwokerto serta memenuhi kriteria inklusi sampel. Analisis statistik dilakukan untuk membandingkan ekspresi relatif mRNA BRLF1 stadium yang berbeda. Nilai ekspresi relatif mRNA BRLF1 EBV pada 24 sampel KNF berkisar 99,04415959-1097,496026. Hasil analisis statistik menunjukkan nilai ekspresi relatif mRNA BRLF1 EBV pada stadium awal $(n=5 ; 544,72420 \pm 142,614733)$ lebih tinggi 1,8 kali dibandingkan dengan stadium lanjut $(n=17 ; 395,68612 \pm 293,172201)$, namun peningkatan ekspresi relatif mRNA BRLF1 EBV tidak bermakna secara statistik karena didapatkan nilai $p=0,130(p>0,05)$. Oleh karena itu, ekspresi relatif mRNA BRLF1 EBV dari biopsi jaringan tumor dalam blok parafin tidak berpotensi sebagai petanda biologi molekul patogenesis KNF, khususnya progresivitas tumor pada stadium lanjut KNF.
\end{abstract}

Kata kunci : Ekspresi relatif mRNA BRLF1 EBV, KNF, Petanda biologi patogenesis

\section{Pendahuluan}

Karsinoma nasofaring adalah salah satu jenis kanker yang sulit dideteksi secara dini. KNF merupakan kanker yang mempunyai keunikan dan berbeda dari tumor ganas di daerah kepala dan leher lainnya dalam hal epidemiologi, spektrum gambaran histopatologi, karakteristik klinik dan sifat biologi. Kejadian KNF bersifat endemik di wilayah Asia (Chang \& Adami, 2006). Prevalensi KNF di Indonesia adalah 6,2 per 100.000 penduduk per tahun dengan 13.000 kasus KNF baru setiap tahun (Adham et al., 2012). Berdasarkan rekam medis RSUD Prof. Dr. Margono Soekarjo jumlah kunjungan pasien KNF pada tahun 2013 sebesar 371 pasien dengan 74 
pasien berasal dari wilayah Kabupaten Banyumas, sedangkan pada tahun 2014 jumlah kunjungan pasien KNF sebanyak 332 pasien dengan 73 pasien berasal dari wilayah Kabupaten Banyumas (Dinas Kesehatan Banyumas, 2014).

KNF bersifat multifaktor karena merupakan interaksi antara faktor kerentanan genetik, lingkungan yang bersifat karsinogen, dan infeksi EBV yang dapat menginduksi terbentuknya sel tumor (Rubin et al., 2005). Peningkatan insidensi KNF juga dilaporkan berkaitan erat dengan faktor makanan seperti makanan yang diawetkan (ikan asin), difermentasi, dan diasapi. Makananmakanan tersebut dapat meningkatkan kandungan nitrosamin yang dapat mengaktivasi Epstein-Barr virus (EBV) dan menginduksi perkembangan tumor pada KNF. Selain itu, konsumsi minuman beralkohol juga dapat meningkatkan risiko terkena KNF (Susworo, 2004).

WHO membagi KNF atas tiga tipe berdasarkan gambaran histopatologi yaitu KNF WHO-1, KNF WHO-2 dan KNF WHO-3. WHO KNF WHO-1 ditemukan sekitar 10\% kasus, KNF WHO-2 ditemukan sekitar $15 \%$ kasus dan KNF WHO-3 adalah tipe yang paling sering ditemukan sekitar $75 \%$ kasus (Hendrawan, 2013). Tipe KNF tidak berdiferensiasi (KNF WHO-3) sangat konsisten konsisten terhadap infeksi EBV (Wahyono et al., 2010).

Gejala klinis KNF baru bermanifestasi setelah tumor bermetastasis ke kelenjar getah bening daerah leher (Faiza, 2016). Mayoritas penderita KNF pada saat didiagnosis sudah dalam stadium lanjut (stadium III dan IV). Hal ini memberikan gambaran bahwa pengetahuan dan kesadaran terhadap gejala klinis awal KNF yang rendah dari penderita KNF (Fles et al., 2010). Diagnosis klinis berdasarkan gejala yang ditimbulkan sejauh ini memiliki tingkat keakurasian yang masih rendah, terutama pada saat pasien berada pada stadium awal yang berakibat pada terjadinya kesalahan diagnosis (Radji, 2010).

Pengukuran aktivitas mRNA (transkrip) EBV di lokasi tumor primer secara langsung pada daerah nasofaring perlu dilakukan, karena aktivitas mRNA EBV lebih mencerminkan patogenesis KNF yang sesungguhnya daripada diagnosis serologi dan pengukuran DNA EBV di sirkulasi darah (Feng et al., 2000). Metode realtime RT-PCR (RT-qPCR) telah digunakan untuk mengukur ekspresi relatif mRNA BRLF1 EBV dan mRNA BZLF1 EBV secara in vitro (Chia et al., 2008). Ekspresi mRNA BRLF1 Epstein Barr-Virus merupakan petanda sensitif dan spesifik untuk diagnosis kanker karsinoma nasofaring dan memberikan bukti yang cukup menjanjikan sebagai petanda molekuler untuk deteksi dini, staging, prognosis, dan pemantauan kekambuhan kanker karsinoma nasofaring (Cacais, 2008). Oleh karena stadium lanjut KNF mencerminkan terjadinya progresivitas tumor pada KNF, maka ekspresi re latif mRNA BRLF1 EBV berpotensi sebagai petanda biologi patogenesis KNF terutama progresivitas tumor KNF. Penelitian ini bertujuan untuk mengetahui nilai ekspresi relatif mRNA BRLF1 Epstein-Barr Virus pada beberapa tingkat stadium tumor penderita KNF sebagai petanda biologi potensial dalam patogenesis KNF. Hasil penelitian ini diharapkan dapat memberikan informasi ilmiah mengenai peran biologi molekuler dalam memahami aspek biologi tumor pada KNF.

\section{Metode}

Sampel yang digunakan dalam penelitian ini adalah bahan biologi berupa biopsi jaringan tumor penderita KNF dalam blok parafin yang telah didiagnosis pasti di Bagian Patologi Anatomi RSUD Prof. dr. Margono Soekarjo, Purwokerto. Berdasarkan proporsi jumlah pasien KNF dibandingkan dengan kanker lain adalah 5,46 persen (Incidency Primary Cancer in Indonesia Pathology Base, 1990), maka besar sampel minimal yang diperlukan dalam penelitian ini adalah 22 orang. Sampel penelitian yang digunakan adalah sampel yang memenuhi kriteria inklusi dan eksklusi. Kriteria inklusi subyek penelitian adalah 1) Penderita KNF dengan diagnosis pasti dari hasil pemeriksaan Patologi Anatomi sebelum terapi yang berusia $>15$ tahun; 2) Sampel penelitian yang dapat ditentukan tipe KNF nya, yaitu tipe KNF WHO-3; 3) pasien yang melakukan biopsi jaringan tumor KNF di RSUD Prof. dr. Margono Soekarjo Purwokerto. Kriteria eksklusi subyek penelitian adalah : 1) Penderita yang didiagnosis bukan KNF, misal tumor hidung dan sinonasal, tumor laring, angiofirboma nasofaring belia dan limfoma malignum; 2) Penderita KNF pasca terapi dan mengalami kekambuhan (relaps). Rancangan penelitian ini berupa analitik observasional yang berbentuk studi seran lintang (cross sectional).

\section{Isolasi RNA EBV dari Jaringan Tumor dalam Blok Parafin}

Sebanyak 8 irisan dari sampel biopsi jaringan tumor penderita KNF diambil dan ditambahkan $300 \mu \mathrm{m}$ larutan melting buffer. Kemudian disentrifugasi dengan kecepatan $13.000 \mathrm{rpm}$ selama 20 detik dan diinkubasi pada suhu $72^{\circ} \mathrm{C}$ selama 10 menit. Lysate ditambahkan $20 \mu \mathrm{l}$ Proteinase $\mathrm{K}$ dan diinkubasi pada suhu $60^{\circ} \mathrm{C}$ selama 60 menit. Setelah itu disentrifugasi dengan kecepatan $13.000 \mathrm{rpm}$ selama 1 menit. Lysate dipindahkan ke dalam tabung $1,5 \mathrm{~mL}$ baru (RNAse clean tube) dan ditambahkan $400 \mu \mathrm{l}$ binding buffer, kemudian ditambahkan $800 \mu \mathrm{l}$ $100 \%$ ethanol. Sebanyak $700 \mu \mathrm{l}$ lysate dimasukkan ke dalam spin cartridge dengan tabung koleksi (Tahap 1) dan disentrifugasi 
dengan kecepatan 2900 rpm selama 1 menit. Kemudian larutan dibuang melalui spin cartridge ditampung di dalam tabung koleksi, spin cartridge dipasangkan kembali pada tabung koleksi. Setelah itu Tahap I diulangi dan disentrifugasi dengan kecepatan 2900 rpm selama 1 menit. Kemudian dicuci dengan wash buffer dan diulang sebanyak 2-3 kali perlakuan, sentrifugasi pada kecepatan $13.000 \mathrm{rpm}$ selama 1 menit. $50 \mu \mathrm{l}$ RNA-se free water dipanaskan pada suhu $65^{\circ} \mathrm{C}$, kemudian dimasukkan ke dalam spin cartridge dengan tabung recovery, diinkubasi selama 1 menit, disentrifugasi dengan kecepatan 13.000 rpm selama 1 menit, kemudian larutan ditampung melalui spin cartridge dalam tabung recovery sehingga akan diperoleh larutan RNA kualitas I dengan volume $50 \mu \mathrm{l}$. Prosedur elusi sekali lagi diulang, diperoleh larutan RNA kualitas II. Larutan RNA bisa digunakan untuk analisis RT-PCR dengan diletakkan di atas es. Larutan RNA bisa disimpan pada suhu $-80^{\circ} \mathrm{C}$ (dalam jangka waktu lama).

\section{Sintesis cDNA}

Annealed RNA mix dibuat dalam volume 10 $\mu \mathrm{L}$ dengan mencampurkan 1,0 $\mu \mathrm{L} 50 \mu \mathrm{M}$ Oligo $\mathrm{d}(\mathrm{T}) 20$ primer, 1,0 $\mu \mathrm{L} 10 \mathrm{mM}$ dNTP mix, 7,0 $\mu \mathrm{L}$ Template RNA, 1,0 $\mu \mathrm{L}$ DEPC-treated water. Campuran diinkubasi di waterbath pada suhu $65^{\circ} \mathrm{C}$ selama 5 menit dan diletakkan di atas es selama 2-3 menit. Kemudian cDNA synthesis mix dibuat pada volume $10 \mu \mathrm{L}$ dengan mencampurkan 2,0 $\mu \mathrm{L} 10$ X RT Buffer, 4,0 $\mu \mathrm{L} 25 \mathrm{Mm} \mathrm{MgCl} 2,2,0$ $\mu \mathrm{L}$ 0,1 DTT, 1,0 $\mu \mathrm{L}$ RNaseOUT (140 U/ $\mu \mathrm{L}), 1,0$ $\mu \mathrm{L}$ Superscript III RT (200 U/ $\mu \mathrm{L})$. Annealed RNA Mix dan cDNA synthesis mix dicampurkan dan diinkubasi di waterbath pada suhu $50^{\circ} \mathrm{C}$, selama 50 menit kemudian diinkubasi di waterbath pada suhu $85^{\circ} \mathrm{C}$, selama 5 menit. Sebanyak $1 \mu \mathrm{L}$ Rnase $\mathrm{H}$ dicampurkan, selanjutnya diinkubasi di waterbath pada suhu $37^{\circ} \mathrm{C}$, selama 20 menit. Pengukuran konsentrasi cDNA sampel dilakukan dengan nanodrop spektrofotometer (NanoOne version 4262 V1.7.3) dan konsenterasi dibuat 50 ng.

\section{RT-qPCR Mix}

Campuran qPCR (qPCR mix) dibuat dalam volume $20 \mu \mathrm{L}$ (DyNAmo Flash SYBR Green qPCR Kit - Thermo Scientific) dengan komposisi

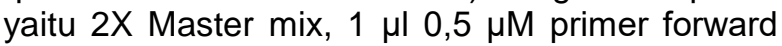

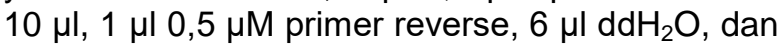
$2 \mu \mathrm{l} 50 \mathrm{ng}$ cetakan cDNA. Amplifikasi dilakukan pada mesin real-time PCR (Bioer - LineGene K FQD 48A) sebanyak 40 siklus dengan kondisi PCR sebagai berikut: denaturasi awal $95{ }^{\circ} \mathrm{C}$ selama 7 menit, denaturasi $95{ }^{\circ} \mathrm{C}$ selama 15 detik, penempelan primer dan pemanjangan 60 ${ }^{\circ} \mathrm{C}$ selama 30 detik. Primer yang digunakan dalam amplifikasi mRNA BRLF1 EBV akan menghasilkan amplikon fragmen cDNA berukuran
$142 \mathrm{pb}$ dengan forward primer 5' GGAGATTCTCTGGCGACTTG-3' dan reverse primer 5'-GAGCCAAAGGAGATCAACCA-3'. Primer gen GAPDH (glyceraldehyde-3-phosphate dehydrogenase) sebagai gen house-keeping yang berfungsi untuk normalisasi nilai $\mathrm{Ct}$ akan menghasilkan amplikon cDNA berukuran $226 \mathrm{pb}$. Primer sisi kiri (forward/left primer) adalah 5'GAAGGTGAAGGTCGGAGT-3'dan primer sisi kanan (reverse/right primer) adalah 5'GAAGATGGTGATGGGATTTC-3' (Chia et al., 2008).

Ekspresi relatif mRNA BRLF1 dihitung berdasarkan atas rumus $2^{-\triangle \mathrm{Ct}}=2^{-[\mathrm{Ct}(\mathrm{BRLF} 1)-\mathrm{Ct}(\mathrm{GAPDH})]}$ (Livak \& Schimttgen, 2001). House keeping genes adalah gen yang ekspresinya tidak berubah dalam kondisi eksperimen. Gen GAPDH (Glyceraldeyde-3-phosphat dehydrogenase) merupakan house keeping gene yang ekspresinya paling stabil, sehingga digunakan sebagai kontrol internal dalam RT-qPCR (Barber et al., 2005). Analisis statistik dilakukan untuk menyajikan analisis Box Plot nilai median ekspresi relatif $\mathrm{mRNA} B R L F 1$ EBV dengan program SPSS berdasarkan atas pengelompokan stadium KNF.

\section{Hasil dan Pembahasan}

Penelitian ekspresi relatif mRNA BRLF1 Epstein- Barr Virus dari biopsi jaringan tumor dalam blok parafin sebagai petanda biologi patogenesis karsinoma nasofaring (KNF) menggunakan 24 sampel berupa biopsi jaringan tumor KNF tipe WHO-3. Sampel penelitian yang diambil adalah sampel yang memenuhi kriteria inklusi dan eksklusi dengan teknik consecutive sampling yaitu semua subjek yang datang dan memenuhi kriteria inklusi dimasukkan dalam penelitian sampai jumlah subjek yang diperlukan terpenuhi. Data pasien didapatkan dari rekam medis diagnosa pasti Poli Patologi Anatomi kemudian dicocokkan dengan diagnosis stadium dari Poli Radioterapi.

Pengukuran mRNA BRLF1 dilakukan menggunakan teknik Reverse Transcriptasequantitative Polymerase Chain Reaction (RTqPCR). Konsentrasi dan kemurnian cDNA pada sampel penelitian ini diukur lebih dahulu menggunakan nanodrop sebelum diamplifikasi. Konsenterasi cDNA dari sampel penelitian ini memiliki kisaran nilai 452-1244 $\mathrm{ng} / \mu \mathrm{L}$, sehingga menunjukkan konsentrasi yang tinggi. DNA dengan rasio $\lambda 260 / 280 \mathrm{~nm}$ pada kisaran antara 1,8-2,0 memiliki kemurnian sesuai persyaratan kemurnian dalam analisis molekuler. DNA dikatakan murni apabila mempunyai nilai perbandingan absorbansi $\lambda$ 260/280 nm berkisar 1,8 - 2,0. DNA yang memiliki nilai absorbansi lebih rendah dari 1,8 menunjukkan sampel DNA terkontaminasi oleh protein, sedangkan kemurnian DNA yang nilainya lebih tinggi dari 2,0 
artinya sampel DNA terkontaminasi oleh RNA (Sambrook \& Russel, 1989).

Kemurnian cDNA dari 24 sampel yang digunakan berkisar 1,000-1,707, sehingga kemurnian cDNA $<1,8$ yang menunjukkan sampel masih terkontaminasi protein. Kuantitas RNA yang baik dibutuhkan untuk melakukan reverse transcription yang optimal, sehingga diperoleh cDNA dengan kuantitas yang baik (Godfrey et al., 2000). Kemurnian cDNA ditentukan dengan perbandingan hasil absorbansi pada $\lambda$ 260/280. Rendahnya kemurnian cDNA ini dapat berasal dari rendahnya kemurnian RNA yang didapatkan dari isolasi jaringan tumor pada parafin. Kemurnian RNA dalam penelitian ini pada $\lambda$ 260/280 adalah 1,4333 - 2,333.

Sampel penelitian yang digunakan dibagi menjadi 2 kelompok yaitu stadium awal (I-II) dan stadium lanjut (III-IV). Tabel 1 menunjukkan nilai ekspresi relatif mRNA BRLF1 dan data stadium setiap sampel. Jumlah sampel stadium awal sebanyak 5 sampel, jumlah sampel stadium lanjut sebanyak 17 sampel, dan 2 sampel tidak diketahui stadiumnya. Sampel yang tidak diketahui stadiumnya tidak diikutsertakan dalam analisis statistik. Nilai ekspresi relatif mRNA BRLF1 EBV pada 24 sampel KNF berkisar 99.04415959-1097.496026. Nilai ekspresi relatif mRNA BRLF1 EBV pada stadium awal memiliki nilai median 533.7424696 (418.765854765.3628153), sedangkan nilai ekspresi relatif mRNA BRLF1 EBV pada stadium lanjut memiliki nilai median $306.5545484 \quad$ (99.044159591097.496026).

Tabel 1. Nilai ekspresi relatif mRNA BRLF1 dan stadium KNF

\begin{tabular}{|c|c|c|c|c|c|}
\hline No & $\begin{array}{l}\text { Kode } \\
\text { Sampel }\end{array}$ & Ct BRLF1 & $\Delta \mathrm{Ct}$ & $2^{-\Delta \mathrm{Ct}}$ & Stadium \\
\hline 1. & 3738 & 24.95 & -8.92 & 484.38152 & IV \\
\hline 2. & 2309 & 25.14 & -8.73 & 424.61161 & IV A \\
\hline 3. & 2558 & 24.8 & -9.07 & 537.45494 & - \\
\hline 4. & 2142 & 25.15 & -8.72 & 421.6786 & ॥ \\
\hline 5. & 2822 & 24.68 & -9.19 & 584.07102 & ॥ \\
\hline 6. & 2721 & 24.81 & -9.06 & 533.74247 & ॥ \\
\hline 7. & 4090 & 25.7 & -8.17 & 288.01497 & IV C \\
\hline 8. & 2465 & 24.66 & -9.21 & 592.22435 & III \\
\hline 9. & 3208 & 23.92 & -9.95 & 989.1188 & IV A \\
\hline 10. & 1810 & 24.59 & -9.28 & 621.66778 & III \\
\hline 11. & 1808 & 24.9 & -8.97 & 501.46319 & - \\
\hline 12. & 1784 & 25.7 & -8.17 & 288.01497 & III \\
\hline 13. & 840 & 25.16 & -8.71 & 418.76585 & ॥ \\
\hline 14. & 1965 & 23.77 & -10.1 & 1097.496 & IV A \\
\hline 15. & 2487 & 24.94 & -8.93 & 487.75065 & III \\
\hline 16. & 2439 & 24.29 & -9.58 & 765.36282 & $\|$ \\
\hline 17. & 1640 & 26.4 & -7.47 & 177.29401 & III \\
\hline 18. & 2070 & 25.61 & -8.26 & 306.55455 & III \\
\hline 19. & 3709 & 26.22 & -7.65 & 200.85353 & IV A \\
\hline 20. & 3274 & 25.94 & -7.93 & 243.87533 & IV A \\
\hline 21. & 309 & 26.97 & -6.9 & 119.42822 & III \\
\hline 22. & 713 & 26.35 & -7.52 & 183.54627 & IV A \\
\hline 23. & 3377 & 26.93 & -6.94 & 122.78581 & IV B \\
\hline 24. & 435 & 27.24 & -6.63 & 99.04416 & III \\
\hline
\end{tabular}

Data yang didapatkan pada penelitian ini menunjukkan stadium awal memiliki ekspresi relatif mRNA BRLF1 yang lebih tinggi dibandingkan dengan stadium lanjut. Steven et al. (2006), menyatakan bahwa pengukuran aktivitas 
mRNA EBV pada lokasi tumor primer perlu dilakukan, karena aktivitas mRNA EBV lebih mencerminkan pathogenesis KNF dibandingkan diagnosis serologi dan pengukuran DNA EBV di sirkulasi. Menurut Chia et al. (2008), ekspresi relatif $m R N A$ BRLF1 lebih tinggi dibandingkan dengan ekspresi BZLF sehingga BRLF1 dianggap memiliki peran lebih dominan pada aktivasi EBV pada karsinoma nasofaring.

Ekspresi relatif mRNA BRLF1 EBV pada biopsi jaringan segar tumor KNF (fresh biopsy) meningkat secara sangat bermakna pada stadium lanjut KNF, terutama antara status $\mathrm{M}_{1}$ (metastasis jauh) dibandingkan dengan status $M_{0}$ (sebelum metastasis jauh) (Wahyono et al., 2016). Berdasarkan penelitian tersebut didapatkan terjadi peningkatan signifikan ekspresi relatif mRNA BRLF1 pada stadium lanjut dibandingkan dengan stadium awal. Hal ini berbeda dengan hasil yang didapatkan pada penelitian ini. Perbedaan ini diduga karena perbedaan keadaan sampel jaringan. Jaringan segar tumor lebih bisa menggambarkan progresivitas tumor karena materi genetik yang diisolasi dari jaringan tumor segar memiliki kualitas yang baik.

Sampel penelitian ini berupa biopsi jaringan dalam blok parafin atau formalin-fixed parafinembedded (FFPE). Penggunaan sampel jaringan tumor dalam blok parafin menghasilkan kualitas materi genetik yang kurang baik karena terjadinya degradasi akibat penggunaan formalin sebagai larutan fiksatif. Hal ini sesuai dengan pendapat Lehman \& Kreipe (2001), fiksasi sampel jaringan menggunakan larutan formalin menyebabkan terjadinya crosslinking pada seluruh komponen jaringan sehingga asam nukleat (DNA dan RNA) mengalami fragmentasi. Berdasarkan penelitian Rezeki et al. (2014), juga menyatakan bahwa proses fiksasi dan pembuatan blok parafin mampu mengubah struktur DNA sewaktu proses fiksasi formalin. Fiksasi jaringan dengan menggunakan formalin dan disimpan dalam waktu lama dapat menyebabkan perubahan struktur dan degradasi DNA.

Gambar 4.1 menampilkan hasil analisis box plot ekspresi relatif mRNA BRLF. Data nilai median pada stadium awal dan lanjut tidak simetris. Hal ini dapat dilihat dari jarak median ke kuartil 1 dan jarak median ke kuartil 3 yang tidak sama panjang pada stadium awal maupun stadium lanjut. Distribusi data pada kedua kelompok juga tidak simetris. Distribusi data dapat dilihat melalui letak garis median dan panjang whisker yang tidak simetris. Nilai median pada stadium awal yaitu 533.7424696 (418.765854$765.3628153)$ dan nilai median stadium lanjut 288.015 (99.04415959-1097.496026).

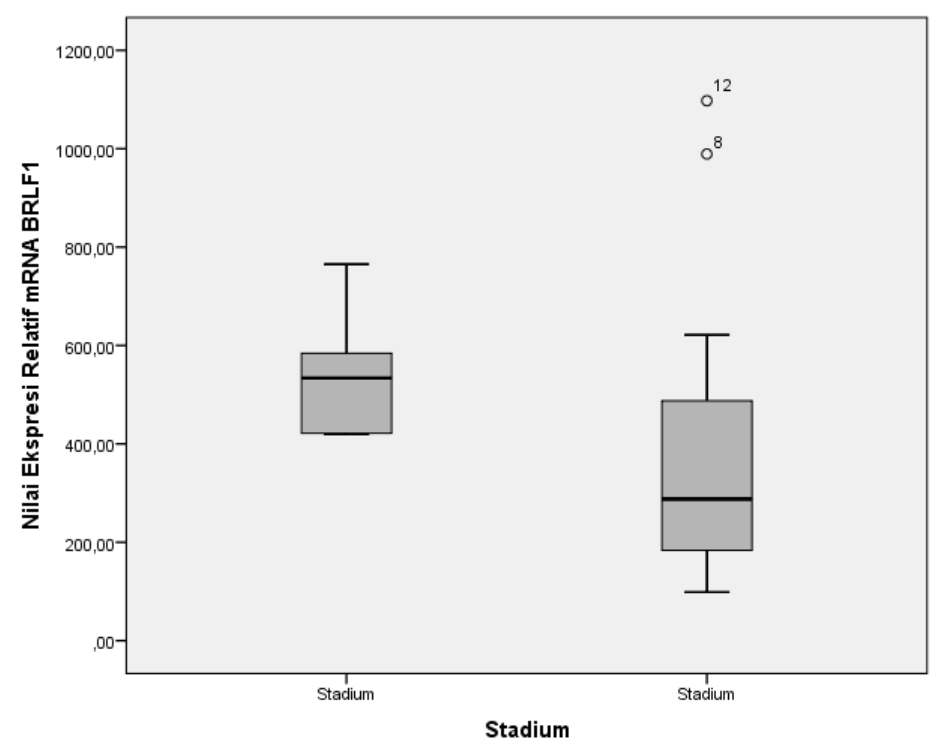

Gambar 1. Analisis Box-Plot ekspresi relatif mRNA BRLF1 EBV pada penderita stadium awal dan stadium lanjut.

Menurut data yang ditampilkan dalam boxplot tersebut distribusi data tidak normal, hal ini dibuktikan dengan adanya nilai ekstrem. Data dikatakan berdistribusi normal bila nilai median ada di tengah-tengah kotak, nilai whisker terbagi secara simetris ke atas dan ke bawah, dan tidak ada nilai ekstrem atau outlier (Dahlan, 2014). Tabel 2 memperlihatkan hasil analisis statistic dengan uji $\mathrm{T}$ independen (SPSS version 15) menunjukkan nilai ekspresi relatif mRNA BRLF1 EBV pada stadium awal $(\mathrm{n}=5 ; 544.72420 \pm$ 142.614733) lebih tinggi 1,8 kali dibandingkan 
dengan stadium lanjut $(\mathrm{n}=17 ; 395.68612 \pm$ 293.172201), namun peningkatan ekspresi relatif
mRNA BRLF1 EBV tidak bermakna secara statistik.

Tabel 2. Hasil Uji T independen

\begin{tabular}{|l|l|r|r|r|r|}
\hline & Group Statistics \\
\hline \multirow{3}{*}{ Ekspresi relatif mRNA } & N & \multicolumn{1}{c|}{ Mean } & Std. Deviation & Std. Error Mean \\
\hline & Stadium Awal & 5 & 544.72420 & 142.614733 & 63.779248 \\
& Stadium Lanjut & 17 & 395.68612 & 293.172201 & 71.104703 \\
\hline
\end{tabular}

Nilai ekspresi relatif BRLF1 mengalami lebih tinggi 1,8 kali pada stadium awal dibandingkan dengan stadium lanjut. Hal ini diduga karena gen litik EBV yang diisolasi dari tumor primer kurang menggambarkan progresivitas tumor. Rangkaian fase litik EBV ditandai dengan adanya lisis sel dan pelepasan virion. Virion akan menyebar dari tumor primer menuju sirkulasi, sehingga isolasi DNA EBVdari tumor primer untuk analisis ekspresi gen litik seperti BRLF1 menjadi kurang efektif. Ekspresi mRNA BRLF1 EBV dari biopsi jaringan tumor dalam blok parafin dapat digunakan untuk diagnosis KNF karena menunjukkan ekspresi yang tinggi pada stadium awal tetapi tidak dapat digunakan untuk prognosis KNF.

Menurut penelitian yang dilakukan oleh Feng et al. (2000), ekspresi BRLF1 pada penderita KNF dapat digunakan sebagai parameter untuk menentukan diagnosis KNF. Antibodi IgG digunakan sebagai parameter serologi karena keterkaitannya dengan Rta (protein yang dihasilkan oleh gen BRLF1). Keberadaan kompleks IgG dan Rta akan menentukan diagnosis dan dapat digunakan untuk screening pasien terduga KNF. Parameter ini memiliki tingkat spesifitas yang cukup tinggi dan untuk meningkatkan sensitivitas dapat dilakukan dengan menggunakan serum dalam jumlah yang lebih banyak. Berdasarkan penelitian tersebut ekspresi BRLF1 yang didapatkan melalui isolasi DNA EBV di sirkulasi darah diketahui cukup spesifik dan sensitif. Hal ini sesuai dengan pendapat Chia et al. (2008), yang menyatakan tingkat DNA EBV di sirkulasi darah merupakan biomarka yang efektif digunakan untuk memantau respon KNF terhadap terapi.

Berdasarkan penelitian terdahulu yang dilakukan oleh Notoputro et al. (2008), dari 25 penderita karsinoma nasofaring dengan kisaran umur 20-60 tahun, 7 orang diantaranya perempuan dan 18 orang lainnya laki-laki. Perbandingan penderita laki-laki dengan perempuan adalah 1,2 : 1. Penelitian yang dilakukan oleh Poida et al (2015) juga menunjukkan distribusi KNF lebih tinggi laki-laki yaitu sebanyak 21 kasus $(61,8 \%)$, sedangkan penderita perempuan sebanyak 13 kasus $(28,2 \%)$. Perbedaan distribusi KNF berdasarkan jenis kelamin berbeda signifikan antara laki-laki dan perempuan yaitu penderita laki-laki sejumlah $23(76,67 \%)$ dan penderita perempuan sejumlah 7 (23,33\%) (Murdiyo et al., 2013).

KNF selalu lebih tinggi ditemukan pada lakilaki (Faiza et al., 2016). Tabel 1 menunjukkan jumlah penderita KNF tipe WHO-3 lebih banyak pada laki-laki. Sebanyak 17 penderita KNF $(70,8 \%)$ dari 24 total sampel yang digunakan dalam penelitian ini adalah laki-laki, dan 7 lainnya $(29,2 \%)$. Rasio antara penderita laki-laki dan perempuan adalah 2,4 : 1. Data yang didapatkan sesuai dengan penelitian terdahulu yang menyatakan bahwa penderita KNF lebih dominan pada laki-laki. Hal ini dikarenakan pola hidup lakilaki yang lebih buruk dari perempuan dan perbedaan intensitas terpapar zat karsinogen, laki-laki cenderung lebih sering terpapar zat karsinogen dibandingkan perempuan sehingga resiko terkena KNF lebih besar.

Tabel 3. Karakteristik berdasarkan jenis kelamin

\begin{tabular}{lcc}
\hline $\begin{array}{l}\text { Jenis } \\
\text { kelamin }\end{array}$ & Jumlah $(\mathrm{n})$ & Persentase $(\%)$ \\
\hline Laki-laki & 17 & 70,8 \\
Perempuan & 7 & 29,2 \\
\hline Jumlah & 24 & 100 \\
\hline
\end{tabular}

KNF dapat terjadi pada setiap usia, namun sangat jarang dijumpai penderita di bawah usia 20 tahun dan usia terbanyak antara 45-54 tahun (Tham et al., 2009). Menurut Guo et al. (2009), insiden kanker nasofaring mulai meningkat setelah usia 30 tahun, 93\% terjadi setelah melewati usia 30 tahun dengan puncak tertinggi saat usia 45-55 tahun. Berdasarkan penelitian yang dilakukan oleh Faiza et al. (2016), didapatkan hasil yaitu secara keseluruhan kisaran umur penderita pasien KNF antara 17-75 tahun dengan angka kejadian terbanyak ditemukan pada dewasa tua dengan kisaran umur 41-65 tahun sebesar $68,18 \%$, diikuti oleh dewasa muda dengan kisaran umur 21- < 41 tahun sebesar $24,99 \%$, kemudian remaja dengan kisaran umur 13- $<21$ tahun sebesar $4.54 \%$, dan kisaran umur yang paling sedikit ditemukan pada manula dengan umur $>65$ tahun sebesar $2,27 \%$.

Distribusi penderita KNF berdasarkan usia digambarkan pada Tabel 4.2. Penderita KNF yang 
digunakan sebagai subjek penelitian ini mayoritas berumur 37-47 tahun yaitu didapatkan sebanyak 10 orang $(41,7 \%)$ dari total sampel penelitian. Kedua terbanyak memiliki kisaran umur 48-58 tahun (33,3\%), diikuti oleh pasien dengan kisaran umur 59-69 tahun (12,5\%), kemudian kisaran umur 26-36 tahun (8,3\%), dan pasien paling sedikit memiliki kisaran umur $15-25$ tahun (4,2\%).

Penelitian Midoen (2010), menunjukkan dari segi faktor umur, jumlah pasien terbanyak adalah pada umur 41-50 tahun $(29,41 \%)$, diikuti umur 51-60 tahun (24,51\%), dan umur 31-40 tahun $(23,53 \%)$ dengan sebaran umur berkisar antara umur 15 sampai dengan 69 tahun. Hal ini sesuai dengan pendapat Savitri \& Haryana (2014), yang menyatakan karsinoma nasofaring banyak terjadi pada usia produktif antara 35-50 tahun. Pendapat ini diperkuat dengan hasil penelitian sebelumnya yang dilakukan di RSCM, yaitu pasien KNF terbanyak ditemukan pada usia 41-50 tahun.

Tabel 4. Karakteristik berdasarkan usia

\begin{tabular}{lrr}
\hline $\begin{array}{l}\text { Kelompok usia } \\
\text { pasien }\end{array}$ & $\begin{array}{l}\text { Jumlah } \\
(\mathrm{n})\end{array}$ & Persentase (\%) \\
\hline 15-25 tahun & 1 & 4,2 \\
26-36 tahun & 2 & 8,3 \\
37-47 tahun & 10 & 41,7 \\
48-58 tahun & 8 & 33,3 \\
59-69 tahun & 3 & 12,5 \\
\hline \multicolumn{1}{c}{ Jumlah } & 24 & 100 \\
\hline
\end{tabular}

Berdasarkan penelitian yang dilakukan oleh Faiza et al. (2016), menunjukkan bahwa mayoritas penderita KNF datang dengan stadium lanjut yaitu sebesar $86,36 \%$, yang terdiri atas stadium III dan IV, diikuti stadium awal yaitu stadium II sebesar 13,64\%, sedangkan stadium I tidak ditemukan. Hal ini memperlihatkan bahwa penderita biasanya telah datang dalam keadaan stadium lanjut dengan gejala berupa massa tumor yang telah menginvasi intrakranial dengan melibatkan nervus kranial, fossa infratemporal, hipofaring, orbit, atau ruang mastikator yang dapat dilihat pada hasil pemeriksaan CT Scan.

Hasil pada Tabel 4.5 menunjukkan karakteristik sampel pasien KNF berdasarkan

\section{Daftar Referensi}

Adham M, Kurniawan AN, Muhtadi Al, Roezin A, Hermani B, Gondhowiardjo S, Tan IB, Middeldorp JM. 2012. Nasopharyngeal carcinoma in Indonesia: epidemiology, incidence, signs, and symptoms at presentation. Chin J Cancer, 31(4), pp. 185-96.

Boyer, R. 2005. Modern Experimental Biochemistry Third Edition. India: Pearson Education Inc. stadium. Data tersebut menunjukkan bahwa pasien yang memiliki stadium lanjut (III-IV) lebih banyak ditemukan daripada pasien dengan stadium awal (I-II). Pasien dengan stadium lanjut didapatkan sejumlah 17 orang $(77,27 \%)$ dan pasien dengan stadium awal didapatkan sejumlah 5 orang $(22,73 \%)$. Perbandingan antara pasien stadium lanjut dan stadium awal adalah sebesar $3,4: 1$. Tingginya angka penderita KNF pada stadium lanjut dikarenakan terlambatnya pasien untuk datang berobat. Mayoritas pasien datang dalam keadaan sudah memasuki stadium lanjut karena KNF tidak memiliki gejala awal yang khas, sehingga sering diabaikan oleh penderita. Diagnosis dini KNF cukup sulit karena letak awal keganasannya yang tersembunyi.

Tabel 5. Karakteristik berdasarkan stadium

\begin{tabular}{|c|c|c|}
\hline Stadium KNF & $\begin{array}{l}\text { Jumlah } \\
(\mathrm{n})\end{array}$ & Persentase (\%) \\
\hline I-II (Awal) & 5 & 22,7 \\
\hline III-IV (Lanjut) & 17 & 77,3 \\
\hline Jumlah & 22 & 100 \\
\hline
\end{tabular}

Keterbatasan pada penelitian ini adalah jumlah sampel yang terbatas untuk analisis statistik. Kondisi spesimen kurang baik karena perlakuan fiksasi sampel dalam larutan formalin sebelum sampel ditanam dalam blok parafin. Selain itu, kontaminasi dalam sampel biopsi parafin pada saat isolasi RNA yang sulit dihindari.

\section{Simpulan}

Nilai ekspresi relatif mRNA BRLF1 dari biopsi jaringan tumor dalam blok parafin berkisar antara 99,04-1097,49. Stadium awal memiliki nilai median 533,74 (418,76-765,36), sedangkan stadium lanjut memiliki nilai median 288,015 (99,04-1097,50). Perbedaan ekspresi antara stadium awal dan stadium lanjut tidak bermakna secara statistik. Oleh karena itu, ekspresi relatif mRNA BRLF1 EBV dari biopsi jaringan tumor dalam blok parafin tidak berpotensi sebagai petanda biologi molekul patogenesis, khususnya progresivitas tumor KNF.

Cacais, A. O. G. 2008. Immunological Consequences of Epstein-Barr Virus Replication. Dissertation. Stockholm, Sweden: Department of Microbiology, Tumor and Cell Biology, Karolinska Institute.

Chang, E.T. \& Adami. 2006. The enigmatic epidemiology of nasoparhyngeal carcinoma. Cancer Epidemiol Biomarkers Prev, 15, pp. 1765-1777.

Chia, M.C., Leung, A., Krushel, T., Alajez, N.M., Lo, K.W., Busson, P., Klamut, H., Bastianutto, C. \& Liu, F-F. 2008. Nuclear 
Factor-Y and Epstein Barr Virus in Nasopharyngeal Cancer. Clin Cancer Res, 14, pp. 984-994.

Dahlan, M.S. 2014. Statistik untuk Kedokteran dan Kesehatan: Deskriptif, Bivariat, dan Multivariat, Dilengkapi Aplikasi Menggunakan SPSS, $6^{\text {th }}$ ed. Jakarta: Epidemiologi Indonesia.

Faiza, S., Sukri, R. \& Aswiyanti, A. 2016. Karakteristik Klinis dan Patologis KNF di Bagian THT-KL RSUP Dr.M.Djamil Padang.Jurnal Kesehatan Andalas, 5(1), pp. 90-96.

Feng, F., Ren, E. C., Liu, D., Chan, S. \& Hhu, H. 2000. Expression of Epstein-Barr Virus lytic gene BRLF1 in nasopharyngeal carcinoma : potensial use in diagnosis. $J$ Gen Virol, 81, pp. 2417-2423.

Fles, R., Wilderman M. A., Sulistiono B., Haryana S. M. \& Tan I. B. 2010. Knowledge of General Practioners about Nasopharyngeal Cancer at Puskesmas in Yogyakarta, Indonesia. BMC Medical Education, 10(81), pp. 1- 6.

Guo, X., Johnson, R.C., Deng, H., Liao, J., Guan, L., Nelson, G.W., Tang, M., Yumin, Z., Guy, D., Stephen, J.O., Cheryl, A.W. \& Yi, Z. 2009. Evaluation of Nonviral Risk Factors for Nasopharyngeal Carcinoma in a High-Risk Population of Southern China. Int.J.Cancer, 124, pp. 29422947.

Hendrawan, A. 2013. Faktor Risiko KNF. CDK204, 40(5), 348-351.

Lehmann, U. \& Kreipe, H. 2001. Real-Time PCR Analysis of DNA and RNA Extracted from Formalin-Fixed and ParaffinEmbedded Biopsies. Methods, 25, pp. 409-418.

Livak, K.J. \& Schimttgen, T.D. 2001. Analysis of Relative Gene Expression Data UsingReal-Time Quantitative PCR and the $2^{-\Delta \Delta C t}$ Method. Methods, 25,8-402.

Midoen, Y.H., Suryandari, D.A., Purnomo, S., Moeloek, N. \& Susworo, R. 2010. Pola Distribusi Alotip Gen Polymeric Immunoglobulin Receptor (PIGR) pada Penderita Karsinoma Nasofaring (KNF) di Indonesia, MKI, 60(11), pp. 489-495.

Murdiyo, M.D., Cici S., Pudji, R., Endang, R. \& Johanes, B.S. 2013. Hubungan mutasi gen ras dan p53 pada penderita karsinoma nasofaring dengan riwayat merokok, ORLI, 43(1), pp. 26-37.

Notopuro, H., Kentjono, W.A. \& Handajani, R. 2008. Karsinoma Nasopharynx dan Infeksi EBV di Indonesia; Analisis Aspek Klinis, Patologi dan Biomolekular. Jurnal Yarsi ISSN, 16 (2).
Gurning, P.P.B., Lubis, M.N.D. \& Delyuzar, M. 2015. Ekspresi LMP1 pada Sel Tumor Sediaan Sitologi Biopsi Aspirasi Kelenjar Getah Bening Leher pada Metastasis Karsinoma Nasofaring. Majalah Patologi, 24(2), pp. 39-46.

Radji. 2010. Imunologi dan Virologi. Jakarta. PT. ISFI.

Rentoft, M. 2012. The Use of Formalin Fixed Paraffin Embedded Tissue and Global Gene Expression Profiling for Increased Understanding of Squamous Cell Carcinoma of The Tongue. University Medical Dissertations, New Series.

Rubin, E., Gorstein, F., Rubin, R., Schwarting, R. \& Strayer, D. 2005. Rubin's pathology: Clinicopathologic foundations of medicine. 4th ed. In: The head and neck: Tumors of the nasopharynx. Baltimore: Lippincott, pp. 5-1294.

Sambrook, J., \& Russel, D.W., 2001. Molecular Cloning: A Laboratory Manual (Third Edition). New York: Cold Spring Harbor Laboratory Press.

Savitri E. \& Haryana S.M. 2014. Hubungan Kadar IL-8 dan IL-10 yang Berpengaruh Terhadap Progresifitas Karsinoma Nasofaring. ORLI, 44(1), pp. 44-51.

Susworo, R. 2004. Kanker Nasofaring: Epidemiologi dan Pengobatan Mutakhir. Cermin Dunia Kedokteran. 144, pp. 916.

Tham, I.W.K., Hee, S.W., Yeo, R.M., Salleh, P.B., Lee, J., Tan, T. W., Fong, K.W., Chua, E.T. \& Wee, J.T. 2009. Treatment of Nasopharyngeal Carcinoma Using Intensity-Modulated Radiotherapy. The National Cancer Centre Singapore Experience. J. Radiation Oncology Biol, 75 (25), pp. 1481-1486.

Wahyono, D.J., Bambang, H. \& Purnomo, S. 2010. Ekpresi gen litik virus EpsteinBarr: mnafaatnya untuk penegakan diagnosis karsinoma nasofaring. Tesis. Jakarta, Program Doktor IImu BiomedikProgram Pascasarjana FKUI.

Wahyono, D.J., Musa, Z., Lisnawati, Suryandar, D.A., Hermani, B. \& Soeharso, P. Penjamu-patogen study: The relative expression of mRNA BRLF1 EpsteinBarr virus : a potensial use for biomarker of tumor progresivity \& polymorphisms of TCRBC and TCRGC2 penjamu genes related to genetic susceptibility on nasopharyngeal carcinoma. BMC Proceeding 2016 : 7th Biannual International Symposium on Nasopharyngeal Carcinoma 2015, Yogyakarta, Indonesi. 